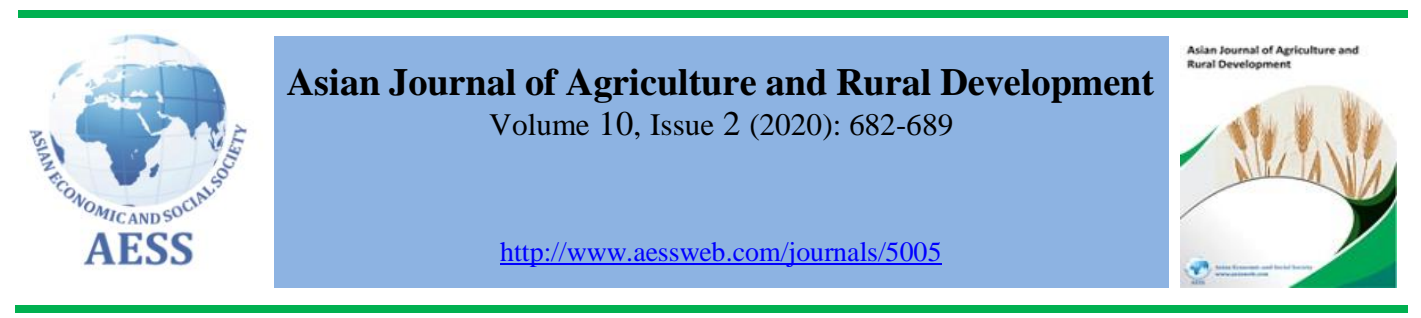

\title{
USE OF ABATTOIR WASTEWATER COMPOST AS ORGANIC FERTILIZER FOR RICE PRODUCTION ON A ULTISOL IN DELTA STATE, NIGERIA
}

\author{
Smart Augustine \\ Ojobor ${ }^{\text {a }}$, \\ Collins N. Egbuchua a
}

\author{
a Department of Agronomy, Delta State University, Asaba Campus, \\ Nigeria
}

\smartojobor@gmail.com (Corresponding author)

\section{ARTICLE HISTORY:}

Received: 25-Mar-2020

Accepted: $31-\mathrm{Jul}-2020$

Online Available: $03-$ Sep2020

\section{Keywords:}

Abattoir wastewater, Organic fertilizer, Oshimilli North,

Rice dust, Soil fertility

ABSTRACT
The research was conducted to monitor the influent of abattoir
wastewater compost on rice growth and yield in Benin-Owah River
Basin in Illah, Delta State, Nigeria. The compost was applied at $0,2.5$,
$5.0,10 \mathrm{t} / \mathrm{ha}$, and NPK15:15:15 at $250 \mathrm{~kg} / \mathrm{ha}$ laid in randomized
complete block design with four replicates. Rice seeds were sown for
two years, and residual effects were evaluated in the third year. Rice
plant height, stem circumference, and the number of tillers was
measured at two weeks intervals while rice yields have taken at
harvest. Soil samples were taken yearly to monitor nutrient changes.
Data obtained were analyzed with analysis of variance and mean
separated with Duncan Multiple Range Test at $\alpha_{0.05}$. In the first year,
NPK15:15:15 significantly gave the highest dry matter $(6.28 \pm 1.45$
t/ha) and grain yield ( $2.4 \pm 0.53 \mathrm{t} / \mathrm{ha})$. While in the second year, $10 \mathrm{t} / \mathrm{ha}$
treatment produced the dry matter ( $7.69 \pm 1.60 \mathrm{t} / \mathrm{ha}$ ) and grain yield
$(2.6 \pm 0.53 \mathrm{t} / \mathrm{ha}$ ). In a residual study, the highest grain yield $(2.8 \pm 0.72$
t/ha) was produced in the plot treated with $10 \mathrm{t} / \mathrm{ha}$, and it also gave the
highest pH, organic carbon, total nitrogen, and available $\mathrm{P}$ content.
The compost at the rate of $10 \mathrm{t} / \mathrm{ha}$ can increase soil fertility and rice
yield.

\section{Contribution/ Originality}

The study has substantiated that compost formulated with abattoir wastewater and rice dusk should be used as a soil amendment for rice production. It also gives opportunities for farmers and agriculturists to start considering alternative use of the waste materials for fertilization because the materials contain nutrient elements. The paper has not been published or presently submitted anywhere for publication.

DOI: 10.18488/journal.ajard.2020.102.682.689

ISSN(P): 2304-1455/ ISSN(E): 2224-4433

How to cite: Smart Augustine Ojobor and Collins N Egbuchua (2020). Use of Abattoir wastewater compost as organic fertilizer for rice production on a ultisol in Delta State, Nigeria. Asian Journal of Agriculture and Rural Development, 10(2), 682-689.

(C) 2020 Asian Economic and Social Society. All rights reserved. 


\section{INTRODUCTION}

Wastes generated through agricultural processing caused negative effects on the environment, creating potential danger such as foul odour and forming breeding grounds for pathogen but can be converted through proven technology into valuable material which can be used as a soil amendment (Schneider et al., 2010 and Gayathri et al., 2019). Commonly used methods of wastes disposal are landfilling and open incineration. Landfilling method can contaminate groundwater through leaching, and even as the population increases, it is difficult to find a suitable site for wastes disposal. Open incineration has a tendency to increase air pollution that requires expensive techniques to control its emissions. Animal production and processing generate large amounts of waste with an outdated waste management system, most notably in developing countries. The increase in waste generation also accelerates greenhouse gas production that had a negative impact on the ecosystem (Huynh et al., 2006).

Wastewater is one category of wastes that emerges from agricultural activities, and it increases with the increasing population. Some sources of wastewater include cassava processing, beverage industry, abattoir, rubber factory, fertilizer factory, and palm oil processing mill, etc. (Liu and Haynes, 2011). Abattoir is one primary source of wastewater among the industries due to the drive to increase meat production for the growing population. Still, the challenges facing the sector is how to manage the indiscriminate disposal of the wastewater in the environment (Omole and Ogbeyi, 2013). The wastewater is composed of urine, blood, water, dissolved solids, pieces of meat, manure. According to Olarewaju and Olofayo (2004), wastewater contains minerals, metals, and microorganisms. It was used for irrigation, and the results showed that it significantly increased plant growth, total herbage production, and nutrients uptake (Sparling et al., 2006 and Castro et al., 2011). The abattoir wastewater can be a source of water and soil nutrients, so; it is important to assess its potential for compost making. If the wastewater with low $\mathrm{C}: \mathrm{N}$ ratio (6:2) is used to compost rice dust (C:N ratio 83:1), it will enhance the quality of the rice dust, which can be used for soil amendment (Thiyageshwari et al., 2018). Advantage can be taken off the rice dust that is available in rice farming communities (Adeoye et al., 2005). Limited information on the use of abattoir wastewater for compost making, is hindering its utilization (Adeoye et al., 2005 and Ojobor, 2018).

Composting is a technology that is successfully used to convert organic waste into useful and stable material through microbial activities, and it is viewed as a flexible technology than incineration (Rockson, 2014). Use of abattoir wastewater and rice dust for compost making will reduce the cost of inorganic fertilizers, the stress it unleashed on farmers to obtained it due to nonavailability, and also reduce the negative impact on the environment. Composting the wastes for soil amendment now that the federal government of Nigeria is emphasizing on food sufficiency through crop production will play a significant role in improving soil fertility. The Nigeria government food selfsufficiency policy can only be achieved through good soil management practices that can improve the declining soil fertility (Vanlauwe et al., 2001). The current practice of using inorganic fertilizer cannot improve the declining soil fertility but with an organic fertilizer that is made with known quality. Therefore, if the abattoir wastewater is carefully used for compost making, it can be used to amend soil fertility of a Ultisol at the Benin-Owah River Basin, Illah, Delta State. The community is allocated over 3,000 ha of land for rice, but due to poor soil fertility, only 550 ha is being used. Hence, this study monitored the influent of abattoir wastewater compost for rice production in Benin-Owah River Basin, Illah, Delta State, Nigeria.

\section{METHODS}

\subsection{Location of study}

The study was conducted at the Benin-Owah River Basin, Illah, Oshimilli North L. G. A., Delta State, Nigeria (Coordinates: 6 ${ }^{\circ} 5^{\prime} 26^{\prime \prime} \mathrm{N} 6^{\circ} 38^{\prime} 56^{\prime \prime} \mathrm{E}$ ) during 2017 and 2018 cropping year in a 
Ultisol. A FARO 52 rice variety was sown in a completely randomized block design. The site was previously used for rice cultivation, and the last harvest was in 2015 and was left fallow in 2016. The dominant weeds in the area were Chromolaena odorata and Aspilia africana. The compost was applied at 2.5, 5, and $10 \mathrm{t} \mathrm{ha}^{-1}$ while NPK15:15:15 was at 250 kg/ha with control in four replicates. Application of compost was made a week before sowing in an area of $361 \mathrm{~m}^{2}$ that was demarcated into a plot of $3 \mathrm{~m}$ by $4 \mathrm{~m}$, and a space of $1 \mathrm{~m}$ was used to separate the plots at a spacing of $25 \mathrm{~cm}$ by $30 \mathrm{~cm}$.

\subsection{Composting}

Rice dust (RD) was obtained from Onicha rice mill, Anambra State, and abattoir wastewater (Aww) was obtained from Ogbe-Ogonogo market, Asaba, Delta State, Nigeria. One hundred kilograms of RD and 35 liters of Aww were used to mix each heap in three replicates. The materials were turned and mixed periodically and moisture content was maintained at $60 \%$ by adding Aww for 12 weeks. The materials were characterized for their nutrient concentration before composting: the RD had: $24.5 \%$ organic carbon (OC), $0.30 \%$ total nitrogen (TN), $0.18 \%$ phosphorus $(\mathrm{P}), 0.21 \%$ potassium $(\mathrm{K}), 0.16 \%$ calcium $(\mathrm{Ca}), 0.50 \%$ magnesium $(\mathrm{mg}), \mathrm{C}: \mathrm{N}$ ratio of $85: 1$ and $\mathrm{pH}$ of 7.1 while Aww had: $14.6 \% \mathrm{OC}, 2.12 \% \mathrm{TN}, 2.01 \% \mathrm{P}, 0.66 \% \mathrm{~K}, 0.33 \% \mathrm{Ca}, 0.73 \%$ $\mathrm{Mg}, \mathrm{C}: \mathrm{N}$ ratio of 6.1 and $\mathrm{pH}$ of 7.8. After composting the material was further characterized with the following values: OC (21.8\%), TN (0.76\%), P (3.11\%), K (1.32\%), Ca (1.15\%), Mg (1.44\%), $\mathrm{C}: \mathrm{N}$ ratio (28.7) and $\mathrm{pH}$ of 7.2.

\subsection{Data collection}

Growth data [height $(\mathrm{cm})$, stem circumference $(\mathrm{cm})$, and a number of tillers] were measured at two weeks intervals from three weeks after sowing (3 WAS). Yields data were measured at harvest. Samples of soil were taken for pre-planting soil evaluation and yearly for post-harvest soil analysis. Soil texture, $\mathrm{pH}, \mathrm{OC}, \mathrm{TN}, \mathrm{P}, \mathrm{K}, \mathrm{Ca}, \mathrm{Mg}, \mathrm{Na}$, exchangeable acidity were measured while ECEC and base saturation were calculated.

\subsection{Laboratory analysis}

The soil samples were analyzed at the International Institute of Tropical Agriculture, Ibadan, Oyo State. Soil texture was according to Bouyoucos (1951). Soil pH was in 1:2 soil- water suspensions. Walkley Black Method was used for organic carbon determination (see Walkley and Black, 1934). $1 \mathrm{~N}$ ammonium acetate was used to extract exchangeable bases while flame photometer was used to measure $\mathrm{K}$ and $\mathrm{Na}, \mathrm{Mg}$ and $\mathrm{Ca}$ were read with Atomic Absorption Spectrophotometer (Jackson, 1964). Bray-1 was used to extract available P (Bray and Kurtz, 1945). Macro-Kjeldahl method was to determining total nitrogen (Jackson, 1962). Exchangeable acidity was determined, according to Black (1975).

\subsection{Statistical analysis}

Analysis of variance was used to analyze the data with SAS Institute, Inc. (2012) and mean were separated with Duncan Multiple Range Test (DMRT) at 0.05 probability level.

\section{RESULTS}

\subsection{Chemical properties of the soil before fertilizer application and at harvest}

The soil was strongly acidic (pH 5.4), OC (1.8 g/kg) and TN $(0.9 \mathrm{~g} / \mathrm{kg})$ were low. Available P (11 $\mathrm{mg} / \mathrm{kg}$ ) was medium, effective cation exchange capacity $(6.9 \mathrm{cmol} / \mathrm{kg})$ was low and base saturation was high (Table 1). Soil $\mathrm{pH}$ increased significantly with a higher rate of compost. Plot treated with $10 \mathrm{t} \mathrm{ha}^{-1}$ had the highest soil $\mathrm{pH}$ values. Soil $\mathrm{pH}$ values increased significantly. Rates of compost did not correspond to increasing soil OC in the first year but did in the second year. The $10 \mathrm{tha}^{-1}$ of compost gave the highest OC in both years $\left(2.7 \pm 0.53 \mathrm{gkg}^{-1}\right.$ and $8.5 \pm 2.94 \mathrm{gkg}^{-1}$, respectively). Total nitrogen did not increase appreciably in the first year though $10 \mathrm{t} \mathrm{ha}^{-1}$ had the highest value. In the second year, there was a significant difference $(\mathrm{p}<0.05)$, and $10 \mathrm{tha}^{-1}$ also had the highest $(1.6 \pm 0.37$ 
$\left.\mathrm{gkg}^{-1}\right)$ while the lowest was found in control $\left(0.5 \pm 0.37 \mathrm{gkg}^{-1}\right)$. In both years, there were significant incremental differences in values of available phosphorus. The $10 \mathrm{t} \mathrm{ha}^{-1}$ of compost had the highest $\mathrm{P}\left(12 \pm 2.15\right.$ and $18 \pm 4.72 \mathrm{mgkg}^{-1}$, respectively) while NPK treatment had $8 \pm 2.15$ and $9 \pm 4.72 \mathrm{mgkg}^{-1}$, respectively). The $10 \mathrm{t} \mathrm{ha}^{-1}$ had the highest $\mathrm{K}, \mathrm{Ca}, \mathrm{Mg}, \mathrm{Na}$ and ECEC in both years. The same level of compost gave the highest base saturation.

Table 1: Soil fertility before and after fertilizer application

\begin{tabular}{|c|c|c|c|c|c|c|c|c|c|c|}
\hline & pH & $\begin{array}{l}\mathrm{OM} \\
---\mathrm{g} / \mathrm{l}\end{array}$ & N & $\begin{array}{c}P \\
\mathrm{Mg} / \mathrm{kg}\end{array}$ & $\mathbf{K}$ & Ca & $\begin{array}{c}\mathrm{Mg} \\
\mathrm{mol} / \mathrm{k}\end{array}$ & $\mathrm{Na}$ & ECEC & $\begin{array}{c}\text { BS } \\
\text { g/kg }\end{array}$ \\
\hline & & & oil ch & nical pr & ertie & efore & ertilize & ipplica & & \\
\hline & 5.4 & 1.8 & 0.9 & 11 & 1.3 & 2.2 & 1.7 & 0.1 & 6.9 & 923 \\
\hline Rates & & & Soil cl & mical pr & perti & after & rtilizer & pplica & & \\
\hline 0 & $5.0 \mathrm{c}$ & $1.5 b$ & 0.5 & 6de & 0.2 & $1.1 \mathrm{~b}$ & 1.1 & 0.1 & $2.7 b$ & $926 b$ \\
\hline 2.5 & $5.3 \mathrm{a}$ & $2.6 \mathrm{a}$ & 0.6 & $7 \mathrm{~cd}$ & 0.2 & $1.2 \mathrm{~b}$ & 1.2 & 0.2 & $3.0 \mathrm{a}$ & $933 b$ \\
\hline 5.0 & $5.4 \mathrm{a}$ & $2.6 \mathrm{a}$ & 0.6 & $10 \mathrm{~b}$ & 0.3 & $1.7 \mathrm{a}$ & 1.3 & 0.2 & $3.7 \mathrm{a}$ & $946 a$ \\
\hline 10 & $5.5 \mathrm{a}$ & $2.7 \mathrm{a}$ & 0.7 & $12 \mathrm{a}$ & 0.4 & $1.8 \mathrm{a}$ & 1.4 & 0.2 & $4.0 \mathrm{a}$ & $950 \mathrm{a}$ \\
\hline NPK & $5.0 \mathrm{c}$ & $1.6 \mathrm{~b}$ & 0.6 & $8 c$ & 0.2 & $1.2 \mathrm{~b}$ & 1.2 & 0.1 & $3.0 \mathrm{a}$ & $900 \mathrm{c}$ \\
\hline SD & 0.21 & 0.53 & 0.06 & 2.15 & 0.08 & 0.29 & 0.102 & 0.049 & 0.487 & 17.8 \\
\hline & & & Ns & & Ns & & Ns & Ns & & \\
\hline & & & & & & 18 & & & & \\
\hline 0 & $4.9 \mathrm{~b}$ & $1.5 \mathrm{~d}$ & $0.5 \mathrm{~d}$ & $4 \mathrm{e}$ & $0.2 \mathrm{~d}$ & $1.0 \mathrm{~b}$ & $1.0 \mathrm{e}$ & 0.1 & $3.0 \mathrm{c}$ & $767 \mathrm{c}$ \\
\hline 2.5 & $5.5 \mathrm{a}$ & $10.1 b$ & $1.1 \mathrm{~b}$ & $12 \mathrm{c}$ & $0.4 \mathrm{c}$ & $2.2 \mathrm{a}$ & $2.5 \mathrm{c}$ & 0.3 & $5.9 \mathrm{~b}$ & $915 a$ \\
\hline 5.0 & $5.6 \mathrm{a}$ & $10.3 b$ & $1.3 \mathrm{~b}$ & $14 \mathrm{~b}$ & $0.6 \mathrm{~b}$ & $2.3 \mathrm{a}$ & $2.9 \mathrm{~b}$ & 0.4 & $6.8 \mathrm{a}$ & $912 \mathrm{a}$ \\
\hline 10 & $5.7 \mathrm{a}$ & $12.5 \mathrm{a}$ & $1.6 \mathrm{a}$ & $18 \mathrm{a}$ & $0.8 \mathrm{a}$ & $2.7 \mathrm{a}$ & $3.4 \mathrm{a}$ & 0.5 & 7.9a & $937 \mathrm{a}$ \\
\hline NPK & $4.9 \mathrm{~b}$ & $1.5 \mathrm{c}$ & $0.9 \mathrm{c}$ & $9 \mathrm{~d}$ & $0.4 \mathrm{c}$ & $2.0 \mathrm{a}$ & $1.9 \mathrm{~d}$ & 0.1 & $5.2 \mathrm{~b}$ & $846 b$ \\
\hline $\mathrm{SD}$ & 0.35 & 4.12 & 0.37 & 4.72 & 0.20 & 0.56 & 0.831 & 0.16 & 1.65 & 62.2 \\
\hline & & & & & & & & Ns & & \\
\hline
\end{tabular}

Means with the same letters in each column are not significantly different at $\alpha_{0.05}$

Note: Ns - not significant, SD - standard deviation

\subsection{Effect of treatments on rice growth and yield}

In the first year, the NPK plot produced the tallest plants (Table 2). In the second year, plots amended with $10 \mathrm{t} \mathrm{ha}^{-1}$ of compost gave the tallest plants while the control had the least. Stem circumference significantly increased (Table 3) with NPK treatment producing plant the highest circumference in both years. The control plot had no-tiller in both years (Table 4). In the first year, plots with $10 \mathrm{t} \mathrm{ha}^{-1}$ of compost treatment and NPK had two tillers each, $5 \mathrm{t} \mathrm{ha}^{-1}$ had one tiller while $2.5 \mathrm{t} \mathrm{ha}^{-1}$ had no farmer. In the second year, $10 \mathrm{t} \mathrm{ha}^{-1}$ had three tillers, $5 \mathrm{t} \mathrm{ha}^{-1}$ and NPK treatments had two tillers each while $2.5 \mathrm{t} \mathrm{ha}^{-1}$ had one tiller. The NPK treatment produced the highest dry matter yield in the first year, and in the second year, $10 \mathrm{t} \mathrm{ha}^{-1}$ of the compost had the highest dry matter yield (Table 4). The NPK treatment also produced the highest grain yield in the first year, while $10 \mathrm{tha}^{-1}$ had the highest in the second year.

Table 2: Plants height $(\mathrm{cm})$ at 3-11 weeks after sowing

\begin{tabular}{lccccccccccc}
\hline $\begin{array}{l}\text { Application } \\
\text { rates }\left(\mathbf{t ~ h a}^{-\mathbf{1}}\right)\end{array}$ & $\mathbf{3}$ & $\mathbf{5}$ & $\mathbf{7}$ & $\mathbf{9}$ & $\mathbf{1 1}$ & $\mathbf{3}$ & $\mathbf{5}$ & $\mathbf{7}$ & $\mathbf{9}$ & $\mathbf{1 1}$ \\
& & & $\mathbf{2 0 1 7}$ & & & & & $\mathbf{2 0 1 8}$ & & \\
\hline 0 & 19.2 & $29.1 \mathrm{~b}$ & $35.0 \mathrm{c}$ & $40.4 \mathrm{c}$ & $46.3 \mathrm{e}$ & $17.4 \mathrm{~d}$ & $24.1 \mathrm{~d}$ & $29.0 \mathrm{~d}$ & $32.4 \mathrm{~d}$ & $36.0 \mathrm{~d}$ \\
2.5 & 19.1 & $31.0 \mathrm{~b}$ & $41.2 \mathrm{~b}$ & $50.4 \mathrm{~b}$ & $59.8 \mathrm{~d}$ & $22.3 \mathrm{~b}$ & $32.1 \mathrm{c}$ & $42.8 \mathrm{c}$ & $53.3 \mathrm{c}$ & $64.7 \mathrm{c}$ \\
5.0 & 19.0 & $29.8 \mathrm{~b}$ & $41.5 \mathrm{~b}$ & $52.9 \mathrm{~b}$ & $62.5 \mathrm{c}$ & $20.4 \mathrm{c}$ & $35.9 \mathrm{~b}$ & $46.6 \mathrm{~b}$ & $56.9 \mathrm{~b}$ & $67.3 \mathrm{~b}$ \\
10.0 & 19.0 & $30.5 \mathrm{~b}$ & $41.7 \mathrm{~b}$ & $53.4 \mathrm{~b}$ & $64.0 \mathrm{~b}$ & $25.5 \mathrm{a}$ & $36.9 \mathrm{a}$ & $50.8 \mathrm{a}$ & $65.1 \mathrm{a}$ & $78.7 \mathrm{a}$ \\
NPK & 20.8 & $32.7 \mathrm{ab}$ & $43.4 \mathrm{a}$ & $55.0 \mathrm{a}$ & $66.0 \mathrm{a}$ & $21.3 \mathrm{~b}$ & $32.0 \mathrm{c}$ & $42.6 \mathrm{c}$ & $55.8 \mathrm{~b}$ & $65.3 \mathrm{c}$ \\
\hline
\end{tabular}




\begin{tabular}{lcccccccccc}
\hline SD & $\begin{array}{c}0.69 \\
\mathrm{Ns}\end{array}$ & 1.22 & 2.88 & 5.23 & 7.00 & 2.63 & 4.50 & 7.32 & 10.90 & 14.14 \\
& & & & & & & & & \\
\hline
\end{tabular}

Means with the same letters in each column are not significantly different at $\alpha_{0.05}$

Note: Ns - not significant, SD - standard deviation

Table 3: Stem circumference $(\mathrm{cm})$ at 3-11 weeks after sowing

\begin{tabular}{|c|c|c|c|c|c|c|c|c|c|c|}
\hline \multirow{2}{*}{$\begin{array}{l}\text { Application } \\
\text { rates }\left(\mathbf{t ~ h a}^{-1}\right)\end{array}$} & \multicolumn{10}{|c|}{ Was after sowing } \\
\hline & 3 & 5 & $\begin{array}{c}7 \\
2017\end{array}$ & 9 & 11 & 3 & 5 & $\begin{array}{c}7 \\
2018\end{array}$ & 9 & 11 \\
\hline 0 & $0.19 a$ & $0.24 a$ & $0.24 b$ & $0.24 \mathrm{c}$ & $0.24 d$ & $0.19 \mathrm{~b}$ & 0.23 & $0.23 c$ & $0.23 \mathrm{~d}$ & $0.23 \mathrm{~d}$ \\
\hline 2.5 & $0.14 b c$ & $0.23 a$ & $0.28 b$ & $0.33 b$ & $0.36 \mathrm{c}$ & $0.18 \mathrm{c}$ & 0.23 & $0.28 b$ & $0.33 \mathrm{c}$ & $0.38 \mathrm{c}$ \\
\hline 5.0 & $0.13 \mathrm{c}$ & $0.24 \mathrm{a}$ & $0.28 b$ & $0.33 b$ & $0.36 \mathrm{c}$ & $0.18 \mathrm{c}$ & 0.22 & $0.28 b$ & $0.33 \mathrm{c}$ & $0.38 \mathrm{c}$ \\
\hline 10.0 & $0.13 c$ & $0.17 b$ & $0.26 \mathrm{~b}$ & $0.33 b$ & $0.41 b$ & $0.18 \mathrm{c}$ & 0.22 & $0.30 \mathrm{a}$ & $0.37 b$ & $0.47 \mathrm{a}$ \\
\hline NPK & $0.19 \mathrm{a}$ & $0.25 \mathrm{a}$ & $0.36 \mathrm{a}$ & $0.48 \mathrm{a}$ & $0.51 \mathrm{a}$ & $0.20 \mathrm{a}$ & 0.24 & $0.31 \mathrm{a}$ & $0.39 a$ & $0.49 \mathrm{a}$ \\
\hline SD & 0.028 & 0.029 & 0.041 & 0.077 & 0.087 & $\begin{array}{l}0.004 \\
\text { Ns }\end{array}$ & $\begin{array}{l}0.006 \\
\text { Ns }\end{array}$ & 0.028 & 0.055 & 0.092 \\
\hline
\end{tabular}

Means with the same letters in each column are not significantly different at $\alpha_{0.05}$

Note: Ns - not significant, SD - standard deviation

Table 4: Number of tillers, dry matter and grain yield

\begin{tabular}{lcccccc}
\hline Application & Number of & \multicolumn{2}{c}{ yield t ha $^{-1}$} & Number of & \multicolumn{2}{c}{ yield t ha-1 } \\
rates $\left(\mathbf{t ~ h a}^{-\mathbf{1}}\right)$ & tillers/plant & Dry matter & $\begin{array}{c}\text { Grain } \\
\text { yield }\end{array}$ & tillers/plant & $\begin{array}{c}\text { Dry } \\
\text { matter }\end{array}$ & $\begin{array}{c}\text { Grain } \\
\text { yield }\end{array}$ \\
& & $\mathbf{2 0 1 7}$ & & & 2018 & \\
\hline 0 & $0 \mathrm{~b}$ & $2.83 \mathrm{c}$ & $0.97 \mathrm{~d}$ & $0 \mathrm{~d}$ & $2.68 \mathrm{~d}$ & $0.93 \mathrm{~d}$ \\
2.5 & $0 \mathrm{~b}$ & $3.29 \mathrm{c}$ & $1.51 \mathrm{c}$ & $1 \mathrm{c}$ & $5.21 \mathrm{c}$ & $1.17 \mathrm{c}$ \\
5.0 & $1 \mathrm{a}$ & $5.32 \mathrm{~b}$ & $1.91 \mathrm{~b}$ & $2 \mathrm{~b}$ & $5.71 \mathrm{~b}$ & $2.31 \mathrm{~b}$ \\
10.0 & $2 \mathrm{a}$ & $6.16 \mathrm{a}$ & $2.33 \mathrm{a}$ & $3 \mathrm{a}$ & $7.69 \mathrm{a}$ & $2.60 \mathrm{a}$ \\
NPK & $2 \mathrm{a}$ & $6.28 \mathrm{a}$ & $2.40 \mathrm{a}$ & $2 \mathrm{~b}$ & $5.55 \mathrm{a}$ & $2.01 \mathrm{a}$ \\
SD & 0.894 & 1.45 & 0.53 & 1.02 & 1.60 & 0.65 \\
\hline
\end{tabular}

Means with the same letters in each column are not significantly different at $\alpha_{0.05}$

Note: SD - standard deviation

\subsection{Effects of residual nutrient treatments on rice growth and yield}

Plot treated with $10 \mathrm{t} \mathrm{ha}^{-1}$ of compost had the tallest plants $(69 \pm 12.8 \mathrm{~cm}), 5.0 \mathrm{t} \mathrm{ha}^{-1}$ and NPK plots had $67.2 \pm 12.8$ and $66.4 \pm 12.8 \mathrm{~cm}$, respectively while the control had $35.1 \pm 12.8 \mathrm{~cm}$ (Table 5). The $10 \mathrm{t} \mathrm{ha}^{-1}$ of compost gave the fattest stem circumference $(0.40 \pm 0.069 \mathrm{~cm})$, and control had $0.20 \pm 0.069 \mathrm{~cm}$. Treatment $5.0 \mathrm{t} \mathrm{ha}^{-1}$ and NPK were not significantly different, but both were higher than $2.5 \mathrm{tha}^{-1}$. The number of tillers (3) was higher in plots treated with $10 \mathrm{tha}^{-1}$ of compost. The highest dry matter yield was produced in the plot treated with $10 \mathrm{tha}^{-1}\left(8.12 \pm 1.80 \mathrm{tha}^{-1}\right)$ and was significantly higher than the lower rates. Grain yield was significantly different, $10 \mathrm{t} \mathrm{ha}^{-1}$ of compost produced the highest grain yield $\left(2.8 \pm 0.72 \mathrm{t} \mathrm{ha}^{-1}\right)$.

Table 5: Residual effects of treatments on growth and yield of rice

\begin{tabular}{lccccc}
\hline $\begin{array}{l}\text { Application } \\
\text { rates }\left(\mathbf{t ~ h a}^{-\mathbf{1}}\right)\end{array}$ & $\begin{array}{c}\text { Plant height } \\
(\mathbf{c m})\end{array}$ & $\begin{array}{c}\text { Stem } \\
\text { circumference } \\
(\mathbf{c m})\end{array}$ & $\begin{array}{c}\text { Number } \\
\text { of tillers }\end{array}$ & $\begin{array}{c}\text { Dry matter } \\
------t\end{array}$ & $\begin{array}{c}\text { Grain yield } \\
\text { ha }^{-1}-----\end{array}$ \\
\hline 0 & $35.1 \mathrm{~d}$ & $0.20 \mathrm{c}$ & $0 \mathrm{~d}$ & $2.53 \mathrm{~d}$ & $0.67 \mathrm{~d}$ \\
2.5 & $63.8 \mathrm{c}$ & $0.35 \mathrm{~b}$ & $1 \mathrm{c}$ & $5.63 \mathrm{c}$ & $1.86 \mathrm{c}$ \\
5.0 & $67.2 \mathrm{~b}$ & $0.36 \mathrm{~b}$ & $2 \mathrm{~b}$ & $6.19 \mathrm{~b}$ & $2.46 \mathrm{~b}$ \\
10.0 & $69.4 \mathrm{a}$ & $0.40 \mathrm{a}$ & $3 \mathrm{a}$ & $8.12 \mathrm{a}$ & $2.81 \mathrm{a}$ \\
\hline
\end{tabular}




\begin{tabular}{lccccc}
\hline NPK15:15:15 & $66.4 \mathrm{~b}$ & $0.36 \mathrm{~b}$ & $0 \mathrm{~d}$ & $5.69 \mathrm{c}$ & $1.96 \mathrm{c}$ \\
SD & 12.77 & 0.069 & 1.17 & 1.80 & 0.71 \\
\hline
\end{tabular}

Means with the same letters in each column are not significantly different at $\alpha_{0.05}$ $\mathrm{SD}$ - standard deviation

\section{DISCUSSION}

Soil $\mathrm{pH}$ of the site was adequate for crop growth and production, but the nutrients were low. Low contents of $\mathrm{OC}, \mathrm{TN}$, and medium-range of $\mathrm{P}$ are an indication that there is a need to improve the fertility of the soil (FMARD, 2012). Therefore, the cultivation of the site without the soil amendment cannot guarantee optimum crop yield.

There was gradual soil $\mathrm{pH}$ increment with increasing application of the compost. This could be the alkaline nature of the compost. Its application increased soil $\mathrm{pH}$ as it mineralized (Santillan et al., 2014). The process of compost mineralization decreased cation fixation that played a significant role in raising the soil $\mathrm{pH}$ (Thiyageshwari et al., 2018). Soil pH values in compost plots were higher than NPK15:15:15 plot that decreases. This could be due to the acid-neutralizing potential of the compost during and after decomposition.

The compost expressed a comparatively higher concentration of nutrient elements than the NPK 15:15:15 and control treatment. It enhanced soil fertility by increasing the nutrient contents and soil organic carbon. The abattoir wastewater, according to Matheyarasu et al. (2015), contains some percentage of elements in organic forms and, if converted to available form during decomposition, can increase the soil nutrient. Organic carbon contents in compost plots were higher, and it might be the fact that waste from abattoir typically contains compounds that are characterized with organic components (Coker et al., 2001; Nafarnda et al., 2006). It could also be responsible for the gradual increase with application levels in both years-the compost enhanced total nitrogen at harvest. Omole and Longe (2008) attributed the high level of total nitrogen to the feces, blood, urine, undigested protein, and digested protein in abattoir wastewater that leads to high microbial decomposition and subsequently releasing nitrogen in the soil. Matheyarasu et al. (2016) also found that abattoir wastewater supplies readily available nitrate-N, ammonia-N, and available $\mathrm{P}$ for plant growth. It might also cause a higher level of total nitrogen observed in compost plots. Mineralization of the successive application of the compost also increased phosphorus in the soil.

Improve soil fertility promoted rice growth, as evidenced by the increased rice yields. Plants treated with compost did better than those in control and NPK plots. Though the NPK treatment did better in the first year, there was a turning point in the second year, where compost treated plants recorded the highest. This shows the potential of the abattoir wastewater compost in improving the soil chemical properties. Glick (2012) and Matheyarasu et al. (2016) noted that the used of abattoir wastewater for irrigation increase crop growth by facilitating nutrients supply and also inhibit the effects of pathogens on crops. This could account for the increased growth and development that resulted in higher dry matter and yield production. Sparling et al. (2006) noticed that the abattoir wastewater application significantly increased the annual and total herbage production, and $\mathrm{N}$ and $\mathrm{P}$ uptake from soils. Rice plants were taller in the second year due to increased nutrient released, and this gave room for higher rice yields. The increased nutrients released from compost resulted in a high rate of cell division that enhanced dry matter and rice grain yield production (Mengel and Kirby, 1987).

Higher residual nutrient pool in compost plots, as shown in the results, could be ascribed to the slow mineralization of nutrients that led to a higher growth rate, as evident with the application of $10 \mathrm{t} \mathrm{ha}^{-1}$ of the compost. It proves that the abattoir wastewater compost had residual value. Improved soil fertility due to abattoir compost application increases rice yields (Glick, 2012). As 
soil fertility was enhanced, nutrients were released to the rice plant for growth and development; this, however, reflected in higher grain yield of rice produced (Picchioni et al., 2012).

\section{CONCLUSION}

Abattoir wastewater and rice dust were used for compost formulation to produced rice at the rate of 2.5, 5.0, $10 \mathrm{t} / \mathrm{ha}$ and NPK15:1515 at the rate of $250 \mathrm{~kg} / \mathrm{ha}$ with a control on an ultisols for two years. In the first year, NPK15:15:15 gave the highest growth and yield of rice; however, $10 \mathrm{t} / \mathrm{ha}$ of the compost had highest in the second year. While in residual nutrients study, $10 \mathrm{t} / \mathrm{ha}$ of the compost significantly increased rice yield and soil chemical properties. Therefore, the abattoir wastewater compost proves to be effective for rice production.

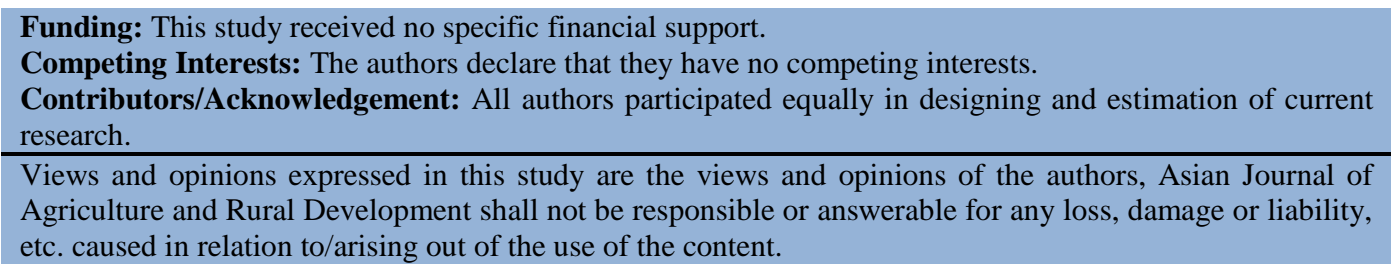

\section{References}

Adeoye, G. O., Ojobor, S. A., \& AdeOluwa, O. O. (2005). Evaluation of potential of co-compost of rice waste, cow dung and poultry manure for production of rice. Proceedings of the $29^{\text {th }}$ Annual Conference of Soil Science Society of Nigeria held at the University of Abeokuta, Abeokuta, Nigeria, Dec. 6-10, 2004, 213-218.

Black, C. A. (1975). Methods of soil analysis. Agronomy No. 9, Part 2. America Society of Agronomy, Madison, Wisconsin. Pp 891-901.

Bouyoucos, C. N. (1951). Recalibration of the hydrometer method for making mechanical analysis of soils. Agronomy Journal, 43, 434-438. doi.org/10.2134/agronj1951.00021962004300090005x.

Bray, R. H., \& Kurtz, L. T. (1945). Determination and fractional organic and available forms of phosphorus in soil. Science Journal, 59, 39-45.

Castro, E., Manas, M. P., \& Heras, J. d. L. (2011). Effects of wastewater irrigation on soil properties and turf grass growth. Water Science and Technology, 63(8), 1678-1681.

Coker, A. O., Olugasa, B. O., \& Adeyemi, A. O. (2001). Abattoir and wastewater quality in South Western Nigeria: In Proceedings of the $27^{\text {th }}$ water. Engineering and Development Center Conference, Lusaka, Zambia pp. 329-331.

FMARD (2012). Literature review on the soil fertility investigation in southern Nigeria. Federal Ministry of Agriculture and Rural Development. Edited by Chude V. O., $2^{\text {nd }}$ Edition. 250p

Gayathri, U., \& Ramasamy, V. (2019). Utilization of Liquid Fertilizers for Agro-Industrial Waste Management and Reducing Challenges through Nano-encapsulation-A Review. Indian Journal of Agricultural Research, 53(3), 641-645.

Glick, B. R. (2012). Plant growth-promoting bacteria: mechanisms and applications. Publishing Corporation, Scientifica: Waterloo, Canada.

Huynh, T. T. T., Aarnink, A. J. A., Drucker, A., \& Verstegen, M. W. A. (2006). Pig Production in Cambodia, Laos, Philippines, and Vietnam: A Review. Asian Journal of Agriculture and Development, 4(1), 69-90.

Jackson, M. L. (1962). Soil chemical analysis. New Delhi, Prentice-Hall of India Pvt. Ltd. Pp 261.

Jackson, M. L. (1964). Soil Chemical Analysis. Pergaman Press, New York. 432p.

Liu, Y. Y., \& Haynes, R. (2011). Origin, nature, and treatment of effluents from dairy and meat processing factories and the effects of their irrigation on the quality of agricultural soils. Critical Reviews in Environmental Science and Technology, 41(17), 1531-1599. doi.org/10.1080/10643381003608359. 
Matheyarasu, R., Bolan, N. S., \& Naidu, R. (2016). Abattoir wastewater irrigation increases the availability of nutrients and influences on plant growth and development. Water Air Soil Pollution, 23, 22633- 22646. doi.org/10.1007/s11270-016-2947-3.

Matheyarasu, R., Seshadri, B., Bolan, N. S., \& Naidu R. (2015). Impacts of abattoir waste-water irrigation on soil fertility and productivity. irrigation and drainage - sustainable strategies and systems. Research Gate pp55.75.

Mengel, K., \& Kirkby, E. A. (1987). Principles of plant nutrition. International Potash Institution, Bern, Switzerland. 687p.

Nafarnda, W. D., Yaji, A., \& Kubkomawa, H. I. (2006). Impact of abattoir waste water on aquatic life: A case study of Yola abattoir. Global Journal of Pure and Applied Science, 12(1), 3133. doi.org/10.4314/gjpas.v12i1.16540.

Ojobor, S. A. (2018). Rice husk-based compost as organic fertilizer for upland rice production in Delta State, Nigeria. A Ph.D. Thesis, Department of Agronomy, University of Ibadan, Oyo State, Nigeria pp 153.

Olarewaju, O., \& Olufayo, A. A. (2004). Physico-chemical and microbiological characteristics of effluents of major abattoirs in Akure, Nigeria. Proceedings of the Nigerian Institution of Agricultural Engineers, 224-229.

Omole, D. O., \& Ogbeyi, A. S. (2013). An evaluation of slaughterhouse wastes in South-west Nigeria. American Journal of Environmental Protection, 2(3), 85-89.

Picchioni, G. A., Shukla, M. K., Mexal, J. G., Babcock, M., Ruiz, A., Sammis, T. W., \& Rodriguez, D. S. (2012). Land application of treated industrial wastewater on a Chihuahuan Desert Shrub land: implications for water quality and mineral deposition. Arid Land Research and Management, 26(3), 211-226.

Rockson, G. N. K. (2014). Composting of abattoir waste and river reed: effect of feedstock and aeration mechanism on process efficiency. A Thesis Agricultural Engineering Department, Kwame Nkrumah University of Science and Technology. Pp. 269.

Santillan, Y. M., Moreno, F. P., \& Garcia, F. P. (2014). Effects of application of manure of cattle on soil chemical properties in Mexico. International Journal of Applied Science and Technology, 4(3), 67-72.

Schneider, U. A., Havlik, P., Schmid, E., Valin, H., Mosnier, A., Obersteiner, M., Bottcher, H., Skalsky, R., Balkovic, J., Sauer, T., \& Fritz, S. (2010). Impacts of population growth, economic development, and technical change on global food production and consumption. Agricultural Systems, 104(2011) 204-215. doi.org/10.1016/j.agsy.2010.11.003.

Sparling, G. P., Barton, L., Duncan, L., McGill, A., Speir, T. W., Schipper, L. A., \& Van Schaik, A. (2006). Nutrient leaching and changes in soil characteristics of four contrasting soils irrigated with secondary-treated municipal wastewater for four years. Soil Research, 44(2), 107-116.

Thiyageshwari, S., Gayathri, P., Krishnamoorthy, R., Anandham, R., \& Paul, D. (2018). Exploration of rice husk compost as an alternate organic manure to enhance the productivity of blackgram in typic haplustalf and typic rhodustalf. International Journal of Environmental Research and Public Health, 15, 358-372. doi.org/10.3390/ijerph15020358.

Vanlauwe, B., Wendt, J., \& Diels, J. (2001). Combined application of organic matter and fertilizer. In G. Tian et al. (ed.) sustaining soil fertility in West Africa. SSSA Special Publication. 58. SSSA and ASA Madison. WI. Pp 247-279.

Walkley, A., \& Black, C. A. (1934). An examination of the Degtjareff method for determining soil organic matter and a propose modification of chromic acid titration method. Soil Science, 39, 29-38. doi.org/10.1097/00010694-193401000-00003. 